(C) М.П. Кляус

\title{
ОБЩЕГРАЖДАНСКИЕ И СОЦИОКУЛЬТУРНЫЕ ЦЕННОСТИ СОВРЕМЕННОЙ МОЛОДЕЖИ ЗАБАЙКАЛЬСКОГО КРАЯ (ПО МАТЕРИАЛАМ АНКЕТИРОВАНИЯ СТУДЕНТОВ ЧИТЫ)*
}

\begin{abstract}
В статье представлены результаты исследования иенностных ориентаций студенческой молодежи Забайкальского края по материалам анкетного опроса студентов разных факультетов Забайкальского государственного университета, проведенного в конце 2020 г. Анкета содержала вопросы, направленные на выявление индивидуальных иенностей и жизненных ориентаций студенческой молодежи. Среди значимых маркеров гражданской активности и досуговых предпочтений рассматривались как современные события и направления жизнедеятельности российского общества, так и эпизодь российской истории, объекты культурного наследия и природные богатства. По результатам опроса было выявлено, что в структуре идентичностей молодежи преобладает гражданская идентичность. В системе жизненных ценностей важную роль играет отношение к историческому опыту, традициям и культуре своего народа. Доминирующим при общении остается русский язык. Опрос показал миграционные настроения студентов, а также желание абсолютного большинства респондентов участвовать в волонтерской деятельности.
\end{abstract}

Ключевые слова: молодежь, ценности, анкетирование, Забайкальский Край, Чита, идентичность

Ссылка при цитировании: Кляус М.П. Общегражданские и социокультурные ценности современной молодежи Забайкальского края (по материалам анкетирования студентов Читы) // Вестник антропологии, 2021. № 4. С. 49-61

\section{Введение и характеристика выборочной совокупности}

Молодежь - главный стратегический ресурс любого государства. Государство и общество понимают, что от состояния молодежи, ее ценностных и жизненных позиций зависит будущее страны. При этом общественное поведение молодого человека является результатом сложного взаимодействия различных факторов, определяющих

Кляус Марина Петровна - к.и.н., научный сотрудник Центра европейских исследований, Институт этнологии и антропологии им. Н.Н. Миклухо-Маклая РАН (РФ, 119334, Москва, Ленинский пр., 32А). Эл. почта: marina_klyaus@mail.ru

* Выполнено в рамках Программы фундаментальных и прикладных научных исследований «Этнокультурное многообразие российского общества и укрепление общероссийской идентичности» по проекту «Российские ценности и символы: национальное единство и этнокультурное многообразие» 
специфику личности и особенности внешних воздействий на нее. Роль молодежи как важного человеческого ресурса и реализация основных направлений молодежной политики отражена, в частности, в Федеральном законе от 30 декабря 2020 г. № 489-Ф3 «О молодежной политике в Российской Федерации» (Федеральный закон 2020).

Не вызывает сомнения необходимость исследований, связанных с молодежной проблематикой: миграционными стратегиями, ценностными приоритетами, с уровнем гражданской и этнической идентичности, с культурными, языковыми и межэтническими отношениями. Этим темам посвящены публикации социологов, психологов, философов, антропологов (Данилюк, Кондаков 2009; Гориков, Шереги 2010; Горшков 2007; Тишков и др. 2014, Дробижева 2009 и др.). Проблема ценностных ориентаций молодежи также заслуживает место в фокусе исследовательского внимания. Именно для антропологов важно понимать ценностные приоритеты данной социально-демографической группы и прогнозировать, на что в ближайшей перспективе могут быть направлены духовные и практические усилия молодежи.

С целью изучения проблем и потребностей современной молодежи, их жизненных стратегий и ценностных установок, в рамках программы Президиума РАН в декабре 2020 г. проводилось анкетирование студентов Забайкальского государственного университета (г. Чита). Всего было собрано 220 анкет, из которых согласно квоте, была сформирована выборка из 200 анкет. В выборку вошли 100 анкет студентов историко-филологического факультета и 100 анкет студентов факультета естественных наук, математики и технологий. Для статистической обработки результатов анкетирования была разработана база данных реализованная в Exel. В данной статье представлен первичный анализ полученных результатов, которые в дальнейшем планируется сопоставить с данными анкетирования студентов в других регионах страны.

Большинство (98\%) опрошенных студентов были в возрасте от 18 до 22 лет, 2\% 23-27 лет. Из них мужчин - 35\%, женщин - 65\%. Учатся и не работают $81 \%$ опрошенных студентов, 14\% совмещают обучение и работу, $3 \%$ кроме обучения занимаются домашним хозяйством, $2 \%$ совмещают работу, учебу и при этом еще ведут домашнее хозяйство. Уровень образования у респондентов следующий:2\% имеют высшее (диплом бакалавра), 7\% - среднее специальное, остальные 91\% - неоконченное высшее, поскольку проходят обучение на данный момент (МПА, 2020).

Нужно отметить, что 92\% респондентов проживают с рождения в данном регионе, и всего лишь 8\% оказались в Чите из других регионов России (Республика Бурятия, Хакасия, Красноярский край). Молодежь как наиболее активная часть населения выступает главным участником социальной мобильности и готова ради реализации собственных интересов и поисков материального благополучия к социальным и территориальным перемещениям. Возможно именно социальная мобильность и желаемое материальное благополучие в будущем объясняет столь высокие показатели внутренней и внешней миграционной активности. При этом, хорошее материальное положение, судя по ответам, имеют только 17\% опрошенных, 53\% отметили в целом нормальное материальное положение, 20\% - затруднительное и 7\% - тяжелое, 3\% опрошенных испытывали затруднение при ответе на данный вопрос.

Опрос показал миграционные настроения студентов, количество планирующих в будущем уехать из региона и страны. На вопрос «Планируете ли Вы уехать в другой регион России или другую страну на длительный срок или на постоянное жительство?» половина опрошенных ответили утвердительно, из них 30\% хотят уехать 
в другой регион России, 19\% - в другую страну. Среди стран предпочтение отдавалось чаще всего США, Австралии и странам западной Европы (Великобритания, Германия, Испания), реже - странам восточной Европы (Польша, Венгрия, Чехия). Есть желающие уехать в скандинавские страны (Норвегия, Швеция) и восточную Азию (Южная Корея, Китай, Сингапур). Среди регионов России предпочтение отдавалось Калининградской области и Краснодарскому краю, реже Республике Хакасия и Ямало-Ненецкому округу. Не удивительно, что приоритетным направлением внутренней миграции стали большие города - Москва, Санкт-Петербург, Иркутск, Тюмень, Сочи. Готовы уехать как в другую страну, так и в другой регион7\% опрошенных. Интересно, что практически четверть опрошенных (22\%) не планируют уезжать из Читы, а остальные $22 \%$ затруднились дать ответ на данный вопрос.

Вполне очевидно, что желание половины опрошенных студентов покинуть в будущем Забайкальский край не совпадает с интересами общества и государственной политики. Особенно устрашающе данные цифры выглядят на фоне процесса интенсивной депопуляции молодежи в стране. Именно этой социально-демографической группе отведена главная роль в воспроизводстве населения и социальной структуры, поскольку ее отличает способность как наследовать, так и преобразовывать социальные структуры. И здесь очень важна объективность в оценке реализации потенциала молодого поколения в интересах многонационального народа Российской Федерации, политического, социально-экономического, демографического и культурного развития страны.

\section{Результаты опроса}

Материалы опроса зафиксировали современные события и направления деятельности государства, которые вызывают у опрашиваемых чувство гордости за свою страну (табл. 1).

Согласно результатам исследования, $45 \%$ опрошенных ценят достижения в области науки, культуры, искусства и спорта, немного меньше (37\%) отметили сохранение этнического многообразия и национальных языков. У 29\% студентов празднование 75-летия Победы в Великой Отечественной войне вызывает чувство гордости за страну. Четверть опрошенных (25\%) оценили укрепление Вооруженных Сил Российской Федерации, 28\% - улучшение возможности профессионального обучения и роста для людей как молодого, так и пожилого возраста; 27\% - борьбу с международным терроризмом, в том числе в Сирии; миротворчество в Нагорном Карабахе; $25 \%$ - развитие туризма в регионах России, $23 \%$ - борьбу с безработицей и бедностью, 20\% - космические полеты, $18 \%$ - развитие военной техники. К сожалению, $9 \%$ опрошенных не нашли среди перечисленных событий и мероприятий те, которые бы вызывали у них чувство гордости за Россию, 11\% затруднились дать ответ.

В системе жизненных ценностей молодежи важную роль играет отношение к историческому опыту, традициям и культуре своего народа. Зачастую, определенные личностные ценностные ориентации, нравственные предпочтения, восприятие символов и ценностей, гражданские установки формируются под влиянием сложившихся в обществе норм, концептов и собственно самой истории. В данном контексте важное значение приобретает выяснение вопроса о том, как молодежь воспринимает факты и события истории своей страны, народа, региона. 
Таблица 1

Распределение ответов на вопрос «Современные события и направления деятельности государства, которые вызывают гордость за Россию» (2020 г., можно было выбрать несколько ответов)

\begin{tabular}{|c|c|}
\hline Варианты ответов & \% от числа опрошенных \\
\hline Если нет таких событий, отметьте только данный пункт & $9 \%$ \\
\hline Борьба с безработицей и бедностью & $23 \%$ \\
\hline Прозрачная система голосования на выборах в органы власти & $6 \%$ \\
\hline Первая в мире вакцина от коронавируса & $13 \%$ \\
\hline Укрепление Вооруженных Сил Российской Федерации & $25 \%$ \\
\hline Достижения в области науки, культуры, искусства и спорта & $45 \%$ \\
\hline $\begin{array}{l}\text { Пенсии, прожиточный минимум, здравоохранение } \\
\text { с } 2020 \text { г. находятся под защитой Конституции }\end{array}$ & $11 \%$ \\
\hline Многопартийность, свобода слова и печати & $14 \%$ \\
\hline Космические полеты & $20 \%$ \\
\hline Развитие военной техники & $18 \%$ \\
\hline Празднование 75-летия Победы в Великой Отечественной войне & $29 \%$ \\
\hline $\begin{array}{l}\text { Улучшение возможности профессионального обучения } \\
\text { и роста для людей как молодого, так и пожилого возраста }\end{array}$ & $28 \%$ \\
\hline Сохранение этнического многообразия и национальных языков & $37 \%$ \\
\hline Создание самого большого в мире атомного ледокольного флота & $16 \%$ \\
\hline $\begin{array}{l}\text { Борьба с международным терроризмом, в том числе в Сирии; } \\
\text { миротворчество в Нагорном Карабахе }\end{array}$ & $27 \%$ \\
\hline Развитие туризма в регионах России & $25 \%$ \\
\hline Другое (напишите) & $2 \%$ \\
\hline Затрудняюсь ответить & $11 \%$ \\
\hline
\end{tabular}

В этой связи, рассмотрим ответы респондентов на вопросы о событиях прошлого, которые вызывают чувство гордости за Россию (диагр. 1). Среди предложенных 7 исторических событий чаще всего респонденты выбирали 2 варианта ответа, на которых приходится $63 \%$ от общего числа полученных ответов. Речь идет, пожалуй, о главных исторических событиях XX века - разгроме гитлеровской Германии и победе Советского Союза в Великой Отечественной войне $(73 \%)$ и о запуске первого в мире спутника и первый полет человека в космос $(75 \%)$.

Четверть (25\%) опрошенных также посчитали важным событием преодоление последствий сталинских репрессий, $18 \%$ - противостояние Советского Союза военному блоку НАТО в годы холодной войны, $12 \%$ - принятие Россией на себя международных обязательств в качестве правопреемника СССР после его распада, 10\% респондентов выбрали вариант ответа - Октябрьская социалистическая революция 1917г., и 10\% -образование Союза Советских Социалистических Республик в 1922 г.; $6 \%$ затруднились при выборе ответа, $6 \%$ не нашли среди предложенных событий 


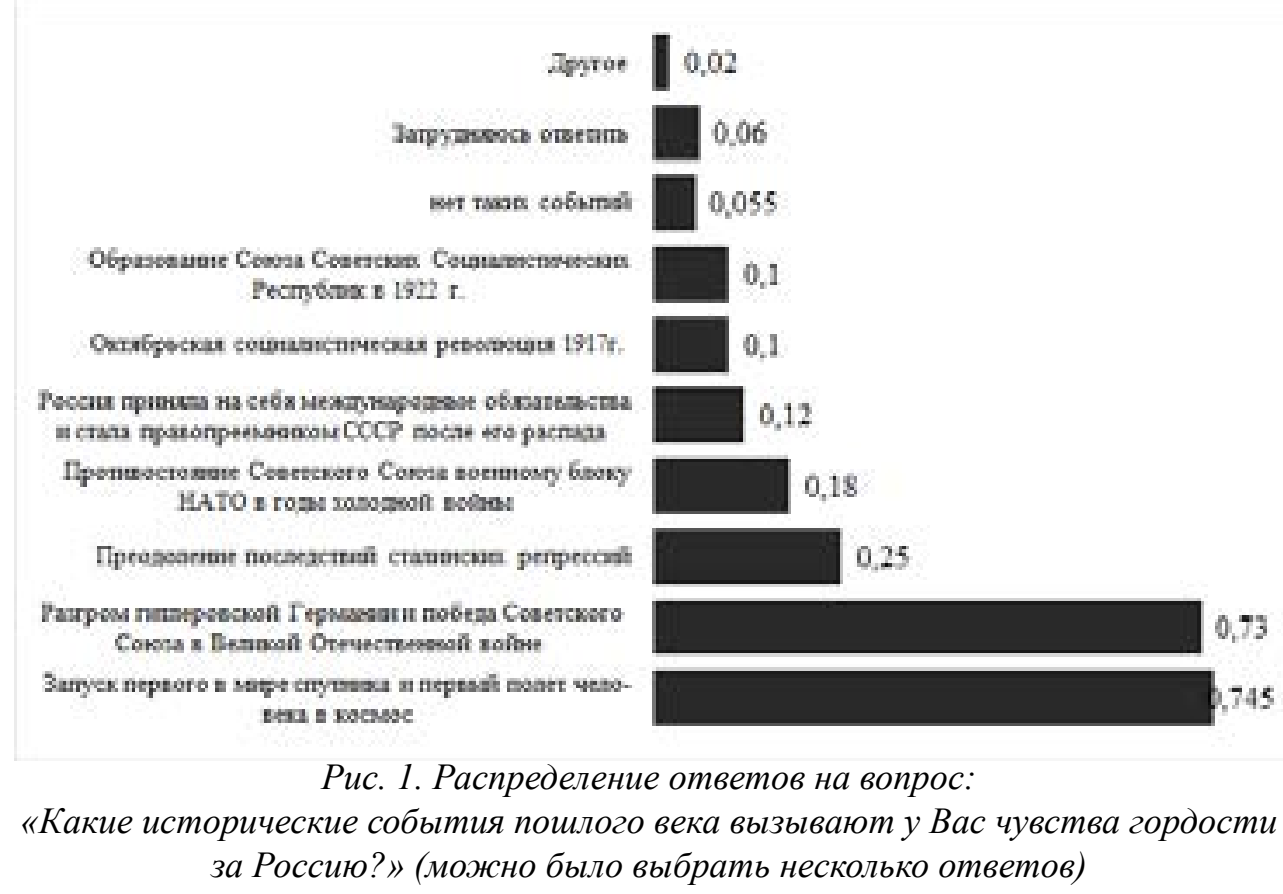

те, которые бы вызывали у них чувство гордости; $2 \%$ опрошенных предложили события, которые, по их мнению, достойны пополнить данный перечень: масштабные демократические реформы 1980-х и 1990-х годов, Эпоха Петра I, походы Суворова, присоединение полуострова Крым к РФ в 2014 г. Следует отметить, что были и другие мнения: «отчего я должен гордиться тем, в чем даже не присутствовал».

Четверть (25\%) опрошенных также посчитали важным событием преодоление последствий сталинских репрессий, $18 \%$ - противостояние Советского Союза военному блоку НАТО в годы холодной войны, $12 \%$ - принятие Россией на себя международных обязательств в качестве правопреемника СССР после его распада, 10\% респондентов выбрали вариант ответа - Октябрьская социалистическая революция 1917 г., и 10\% образование Союза Советских Социалистических Республик в 1922 г.; 6\% затруднились при выборе ответа, 6\% не нашли среди предложенных событий те, которые бы вызывали у них чувство гордости; $2 \%$ опрошенных предложили события, которые, по их мнению, достойны пополнить данный перечень: масштабные демократические реформы 1980-х и 1990-х годов, Эпоха Петра I, походы Суворова, присоединение полуострова Крым к РФ в 2014 г. Следует отметить, что были и другие мнения: «отчего я должен гордиться тем, в чем даже не присутствовал».

В данном контексте интересно проследить гражданскую активность студентов, в частности, желание участвовать в государственных мероприятиях в качестве волонтера. Во время вовлеченности в волонтерскую деятельность формируются и усваиваются подрастающим поколением нормы поведения, навыки, ценности, убеждения, то есть, целый ряд социально-гражданских и личностных качеств и навыков, в которых нуждается современное гражданское общество. Очень важно оценивать вовлеченность студенческой молодежи в волонтерские движения, поскольку в процессе становления личности сознательная добровольческая деятельность на благо других людей и общества в целом благоприятно сказывается на социализации, со- 
циальной активности личности и формирование социально-коммуникативной компетентности (табл.2).

Таблица 2

Распределение ответов на вопрос «Какие из перечисленных государственных мероприятий были бы Вам интересны для участия в качестве волонтера?» (можно было выбрать несколько ответов)

\begin{tabular}{|c|c|}
\hline Варианты ответов & $\begin{array}{c}\text { \% от числа } \\
\text { опрошенных }\end{array}$ \\
\hline Нет таких мероприятий & $10 \%$ \\
\hline День города/села, в котором проживаете, либо учитесь или работаете & $34 \%$ \\
\hline Международный день родного языка (21 февраля) & $14 \%$ \\
\hline День Победы (9 мая) & $51 \%$ \\
\hline День славянской письменности и культуры (24 мая) & $9 \%$ \\
\hline День русского языка (6 июня) & $12 \%$ \\
\hline День России (12 июня) & $26 \%$ \\
\hline Международный день коренных народов мира (9 августа) & $16 \%$ \\
\hline День народного единства (4 ноября) & $17 \%$ \\
\hline Единый день голосования (сентябрь) & $7 \%$ \\
\hline Крупные спортивные мероприятия & $36 \%$ \\
\hline $\begin{array}{l}\text { Мероприятия по продвижению русского языка, российской культуры, } \\
\text { в том числе через интернет }\end{array}$ & $15 \%$ \\
\hline Мероприятия по сохранению и развитию языков и культур народов России & $20 \%$ \\
\hline $\begin{array}{l}\text { Помощь лицам пожилого возраста или } \\
\text { с ограниченными физическими возможностями }\end{array}$ & $48 \%$ \\
\hline Другое & $2 \%$ \\
\hline Затрудняюсь ответить & $8 \%$ \\
\hline
\end{tabular}

Согласно результатам опроса, половина (51\%) респондентов выбрали День Победы, $48 \%$ хотели бы помогать людям пожилого возраста или с ограниченными физическими возможностями. Возможно, такое желание содействовать в оказании социальных услуг пожилым, инвалидам и другим депривированным группам связано с низким показателем признания достижений государства в области здравоохранения и повышения пенсий (11\%), а также с осознанием того, что социальная поддержка населения должна осуществляться не только государством, но и членами общества. Важно преодоление социальной замкнутости, понимание молодежью проблем, с которыми сталкиваются люди пожилого возраста и инвалиды, стремление оказать поддержку нуждающимся. Студенты считают, что государство недостаточно уделяет внимание решению проблем, с которыми сталкиваются указанные группы населения. 
Треть опрошенных хотели бы выступить в качестве волонтеров на крупных спортивных мероприятиях (36\%) и на дне города или села (34\%), четверть респондентов 26\% выбрали День России. 10\% опрошенных не нашли интересных для себя событий и направлений деятельности государства, в качестве волонтера, 8\% затруднились дать ответ. Всего лишь пятая часть (20\%) студентов готова участвовать в мероприятиях, направленных на сохранение и развитие языков и культур народов России, еще меньшим интересом пользуются день русского языка (12\%), день славянской письменности (9\%) и различного рода мероприятия, направленные на популяризацию и продвижение русского языка и российской культуры. Странным выглядит данный показатель, особенно если учесть, что $82 \%$ студентов указали русскую национальность. Не удивляет низкий процент желающих принимать участие в качестве волонтера на голосовании (7\%), поскольку большая часть опрошенных молодых людей еще не участвовала в голосовании. К примеру, лишь 39\% респондентов принимали участие в голосовании о поправках в Конституцию Росси летом 2020 года.

Если учесть низкую частоту выбора среди значимых поправок в конституцию варианта «русский язык - государствообразующий» (всего 16\% опрошенных, 5\% к частоте ответов), и 4\% (12\% опрошенных) ответов, что государство гарантирует сохранение языков, становится очевидным, что языковая проблема меньше всего заботит молодежь. Вполне возможно, студенты считают, что русский язык не нуждается в защите. В повседневном общении все используют русский язык, и популяризация языка не видится актуальной, как и меры государства в сфере языковой политики.

Опрос показал, что 92\% респондентов готовы участвовать в волонтерской деятельности, поскольку хотят быть социально полезными, иметь возможность для реализации личных качеств и получить навыки и умения в разных сферах. Поэтому общество должно направлять активность молодежи в конструктивное русло, что предоставит возможность для решения ряда проблем, таких как социальная защита, благоустройство, экология, профилактика, алкогольной и наркотической зависимости, ВИЧ-инфекций, правозащитная деятельность, сохранение исторического и культурного наследия и т.д. Сегодня при реализации государственных программ по поддержке молодежи во многих странах мира финансируются проекты, направленные на использование молодежной волонтерской деятельности и гражданской вовлечённости в краудсорсинговые проекты.

В анкете были вопросы, направленные на выявление индивидуальных ценностей и смысложизненных студенческой молодежи г. Чита. На вопрос о целях жизни, следует ли добиваться их вместе с окружающими или самостоятельно, ответы распределись следующим образом: 12\% считают, что вместе с окружающими, $36 \%$ - самостоятельно, $31 \%$ выбрали вариант, больше самостоятельно, чем с окружающими, $10 \%$ - больше с окружающими, нежели самостоятельно, $11 \%$ считают, что и вместе с окружающими и самостоятельно.

Дальние цели на будущее оказались важны для 77\% опрошенных, сочли, что они не требуются - 3\%, больше важны, чем не требуются - для 14\% опрошенных, больше не требуются, чем важны - для 4\%, 1\% выбрали вариант, объединяющий «не требуются» и «мне важны», 1\% затруднились дать ответ.

На вопрос «Мои успехи зависят от меня или от окружающих», распределение ответов было следующим: 79\% считают, что от них (вариант «от меня»), 1\% - от окружающих, $10 \%$ - больше от меня, чем от окружающих, $2 \%$ - больше от окружа- 
ющих, нежели от меня, 7\% - и от меня,и от окружающих, 1\% затруднились ответить.

В трудных жизненных обстоятельствах 93\% опрошенных рассчитывают на семью и родственников, 56\% - на друзей и соседей, 9\% - на пользователей соцсетей, $6 \%$ - на волонтеров и общественные организации, 4\% - на местные власти и социальные службы, 2\% - затруднились дать ответ, $1 \%$ - рассчитывает на помощь коммерческих организаций, 5\% - дали другой ответ («на себя»). Чаще всего, студенты выбирали сразу несколько из предложенных вариантов.

Ответы на данные вопросы, показывают, что для большинства респондентов жизненные события рассматриваются по большей части как результат собственных усилий и ориентаций на свои цели.

Интересно оценить распределение ответов на вопрос о восприятии власти, начальников и лидеров. 18\% студентов считают, что «это далекая планета», 42\% «простые люди с соседней улицы», 17\% - больше простые люди с соседней улицы, нежели далекая планета, 9\% выбрали одновременно два ответа, 8\% - больше далекая планета, нежели люди с соседней улицы, $6 \%$ затруднились дать ответ.

Рассмотрим увлечения студенческой молодежи (см. диагр. 2). Результат анкетирования показал, что тотальной зависимости от интернета, социальных сетей и компьютерных игр не наблюдается.

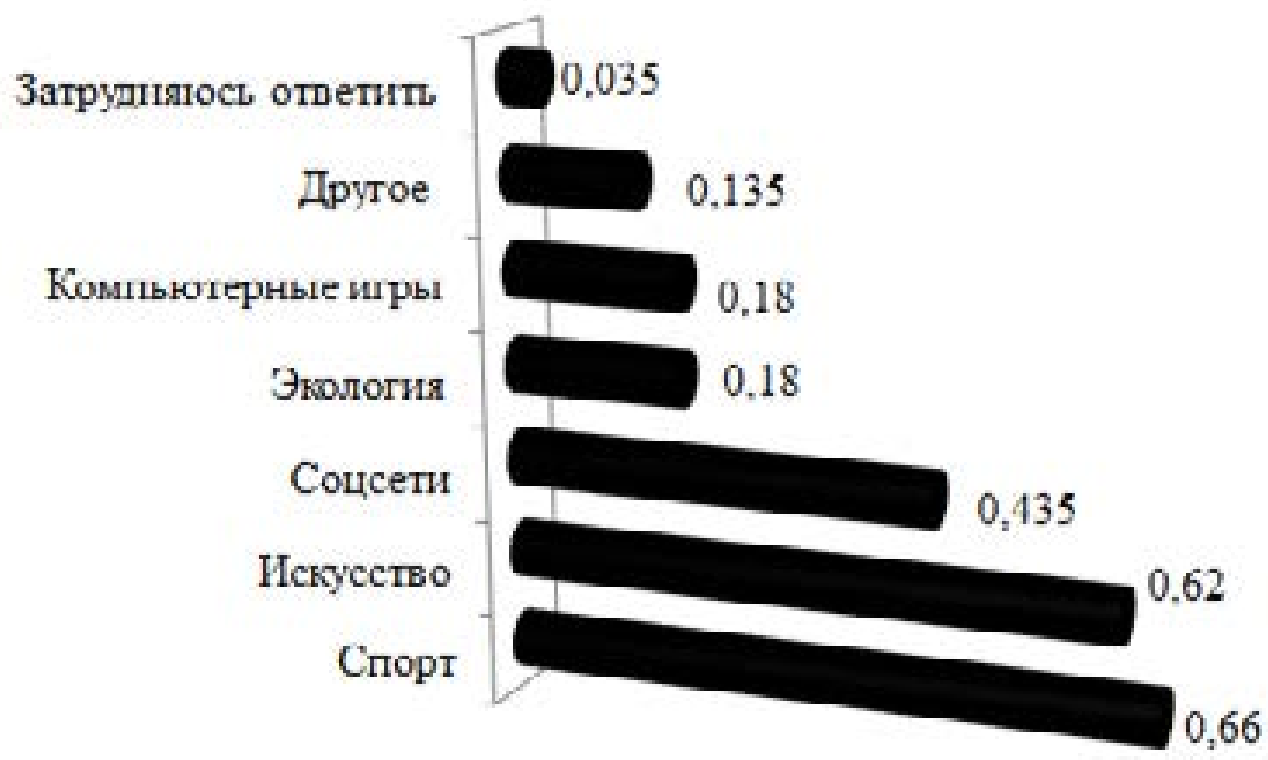

Рис. 2. Распределение ответов на вопрос: «Чем Вы хотели бы заниматься в свободное время - спорт, искусство, соисети, экология, компьютерные игры?» (можно было выбрать несколько ответов).

Пристрастие к социальным сетям проявили 44\% опрошенных, 18\% - к компьютерным играм, еще $18 \%$ студентов предпочитают свободное время тратить на реализацию экологических программ, $62 \%$ отдали предпочтение искусству (чаще всего среди пояснений встречается музыка и танцы), 66\% - спорту, 4\% затруднились ответить, 
14\% предложили свои варианты ответов, среди которых: наука, политика, хобби (рукоделие, изучение космоса, психология, творчество, резьба по дереву, ведение блога, маникюр), путешествия и активный отдых, саморазвитие, волонтерство, чтение.

На вопрос «Если Вам интересны туристические поездки по России, куда хотели бы поехать в следующем году?» $6 \%$ опрошенных ответили, что такие поездки им не интересны, 16\% затруднились ответить, 78\% студентов указали наиболее привлекательные для них места. Самым популярным городом стал Санкт-Петербург, 27\% опрошенных хотят посетить северную столицу страны. Путешествие по забайкальскому региону интересно 17\% студентов, для которых наиболее привлекательными оказались озеро Байкал, национальный парк Алханай и Чарские пески. 12\% студентов хотят посетить Сочи, 11\% Москву, 11\% Крым, Алтайский Край - 9\%, Владивосток - 8\%. 5\% опрошенных интересны Карелия, Краснодарский край, Новосибирск, Калининград; 4\% Камчатку, 3\% - Золотое кольцо, 2\% - Дальний Восток, Екатеринбург. 1\% опрошенных интересны Астрахань, Анапа, Архангельск, Амурская область, Владимир, Дагестан, Сахалин, Севастополь, Ростов-на-Дону, Тула, Хабаровск и Хакасия.

Студентам было предложено пополнить список культурного наследия регионов, городов и сёл страны. Допускалось вносить не только памятники, но и предметы местной культуры, народные промыслы, традиции, праздники, блюда национальной кухни, песни, танцы и прочее. Также предлагалось высказать свое мнение в поддержку или против идеи существования такого списка. Поддерживают идею создания списка культурного наследия $87 \%$ студентов, $2 \%$ не поддерживают, $1 \%$ дали другой ответ («нейтрально»), 10\% затруднились ответить на вопрос о необходимости данного списка, 18\% опрошенных предложили свои варианты.

Среди высказанных позиций для внесения в список культурного наследия были: блюда бурятской национальной кухни (буузы),национальные костюмы, обряды и традиции (сагаалган, рождественские гулянья, свадебные церемонии), танцы (бурятский народный танец Ёхор), памятники архитектуры и музеи (дом купцов Шумовых, дом декабриста М.М. Нарышкина и его супруги Е.П. Нарышкиной, музей «Церковь декабристов»- все в Чите, дворец купца М.Д Бутина в Нерчинске, Сретенский судостроительный завод), храмы (старинные церкви в поселках Забайкальского края), природно-культурные памятники и заповедники (национальный парк Алханай, Чарские пески, Арахлейские озера, Сухотино) города и села (поселение Кутомара, село Толбага), русская литература, культура коренных народов России, промыслы (резьба по дереву, рыболовство, охота), вышивка. Кедровые орешки и тарбаган неоднократно предлагались для внесения в список.

Указали свой родной язык 99\% студентов. Из них 96\% указали один родной язык, $3 \%$ указали два родных языка и $1 \%$ - три. Для 95\% студентов русский язык является родным языком, для 5\% родные другие языки. Среди них указаны: бурятский, армянский, польский, иврит, коми-пермяцкий, мордвинский, коми, украинский, молдавский. При ответе на вопрос «Если вы не общаетесь на родном языке, то по какой причине» (можно было выбирать несколько вариантов), ответы распределились таким образом: $6 \%$ опрошенных не знают или мало знают родной язык, 4\% признали проблему в том, что окружающие не знают их родного языка, $1 \%$ испытывают стеснение при использовании родного языка, 7\% затруднились ответить на данный вопрос, $84 \%$ студентов не испытывают проблем, поскольку общаются с окружающими на своем родном языке. Пояснили выбранные варианты ответов $2 \%$ опрошенных. Чаще всего указывали, 
что нет возможности общаться на родном языке, поскольку окружающие не знают их языка, поэтому выбирают русский язык для повседневного общения.

При общении с друзьями, знакомыми или в семье $22 \%$ опрошенных (44 человека) используют кроме русского языка английский (20 чел.), бурятский (6 чел.), украинский (3чел.), китайский (2 чел.), казахский (1 чел.), остальные 12 человек не указали, какие именно языки используют. Используют только русский язык для общения в семье и с друзьями $78 \%$ студентов.

На вопрос «За последний год приходилось ли Вам испытывать негативное к себе отношение из-за языка, на котором говорите, своей национальности, религии?» 92\% респондентов отметили, что не испытывали никакого негативного отношения, 2\% признались, что испытывали из-за национальности, 2\% - из-за религии, $2 \%$ затруднились ответить, $1 \%$ - из-за языка, $1 \%$ дали другой ответ.

Подавляющее большинство (91\%) опрошенных указали свою национальность, 9\% не указали либо в качестве национальности вписывали варианты - славянин, россиянин, национальность не имеет значения, главное, сущность человека; «я человек», «нейтрален», метис, землянин или просто сообщали, что ни к какой национальности себя не относят. 13\% опрошенных указали вторую национальность, 1\% указал три национальности. Из указавших национальность 182 человек 91\% - русские, $6 \%$ буряты, по 1\% - армяне и эвенки, менее $1 \%$ - евреи и немцы. Среди тех, кто указал вторую национальность, распределение следующее: татары, немцы, мордвины, русские, тунгусы, хакасы, украинцы и туркмены.

Один из вопросов был направлен на выявление уровня этнической, гражданской и региональной идентичностей (табл. 3).

Таблица 3

\section{Распределение ответов на вопрос «Как Вас должны воспринимать окружающие в повседневной жизни, - как гражданина России, или как представителя отдельной национальности, или как жителя определенного региона? (Можно несколько ответов)}

\begin{tabular}{|c|c|}
\hline Варианты ответов & \% от числа опрошенных \\
\hline Как гражданина страны & $78 \%$ \\
\hline Как представителя отдельной национальности & $6 \%$ \\
\hline Как жителя определенного региона & $13 \%$ \\
\hline Другой ответ & $11 \%$ \\
\hline Затрудняюсь ответить & $5 \%$ \\
\hline
\end{tabular}

В целом результаты анкетировании показывают, что в молодежной среде преобладает гражданский тип идентичности. Студенты осознают принадлежность к своему государству, при этом 78\% опрошенных считают, что их должны воспринимать как гражданина страны, 13\% - как жителя определенного региона. Национальную идентичность в качестве ключевой, определили для себя $6 \%$ студентов, затруднились дать ответ - 5\%. Практически 10 часть опрошенных предложила другие ответы: как человека, как личность, как гражданина мира и как жителя планеты земля. Причем довольно часто свои ответы студенты сопровождали комментариями: «Окружаю- 
щие должны воспринимать меня как самостоятельную личность независимо от места моего рождения, страны проживания, религии или национальности».

\section{Выводы}

Основная цель данной статьи заключается в том, чтобы представить результаты анкетирования студентов Забайкальского края. В дальнейшем предполагается продолжить антропологический анализ гражданских и социокультурных ценностей, провести сопоставительный анализ результатов исследования по данной методике с другими регионами страны.

К сожалению, не было возможности в полной мере проследить динамику изменений интересующих нас региональных показателей, т.к. не удалось обнаружить исследований по Забайкальскому краю, которые бы охватывали студенческую молодежь и соответствовали задачам данного проекта. В определенной степени данная тема затрагивается в статье В.Л. Кляуса и М. Ю. Щаповой (Кляус, Щапова 2000). Авторы в 2000-ом году проводили опрос среди студентов филологического факультета Забайкальского государственного гуманитарно-педагогического университета имени Н.Г. Чернышевского (в 2012 г. объединен с Забайкальским государственным университетом). Целью их анкетирования было выявление сюжетов провинциальной мифологии, но помимо прочего студенты ответили и на вопросы о ценностях и своих представлениях о Забайкальском крае, как регионе проживания.

Сопоставление результатов указанной работы и нашего опроса показывает, что в студенческой среде сохраняется определение в качестве главной ценности региона его природно-культурных объектов.

Крайне интересно сравнение результатов по миграционной мобильности. У авторов цитируемой статьи была относительно небольшая выборка, поскольку исследование носило качественный характер. Но они обратили внимание, что среди студентов, которые идентифицировали себя русскими, еще тогда, 20 лет назад, была четко выражена установка уехать из Забайкалья, что совпадает с нашими данными. А вот студенты бурятской национальности подобных желаний не высказывали (Кляус, Щапова 2000:366-367). Видимо, в начале 2000-ых, бурятские студенты не проявляли миграционной активности, считая свой родной край комфортным и благоприятным для жизни регионом, поскольку именно здесь исторически формировался бурятский этнос. Сегодня же, по данным нашего анкетирования, и бурятская молодежь высказывает желание уехать из Забайкалья, чаще всего в Новосибирск и Иркутск. Нам известны некоторые суждения читинцев о том, что выпускники школ города, особенно те, кто окончил с хорошими результатами по ЕГЭ, уезжают обучаться в вузы Сибири, Санкт-Петербурга и Москвы. Это в целом указывает на серьезные проблемы в социальной и экономической сфере развития края, но рассмотрение данного вопроса требует дальнейших исследований.

Проведенный опрос подтвердил, что современная молодежь не рассчитывает на существенную поддержку со стороны государства, видит недочеты в сфере социальной политики и выбирает жизненные стратегии в соответствии с собственными представлениями о том, что для них является важным. 


\section{Источники и материалы}

ПМА 2020 - Полевые материалы автора. Чита 2020, опрос студентов ВУЗов Читы Федеральный закон 2020 - Федеральный закон от 30 декабря 2020 г. N 489-Ф3 «О молодежной политике в Российской Федерации» // СПС КонсультантПлюс. http://www.consultant. ru/document/cons_doc_LAW_372649/(дата обращения: 12.11.2021).

\section{Научная литература}

Данилюк А.Я., Кондаков А.М., Тишков В.А. Концепция духовно-нравственного развития и воспитания личности гражданина России. М.: Просвещение, 2009. 24 с.

Дробижева Л.М. (отв. ред.). Российская идентичность в Москве и регионах / Отв. ред. Л.М. Дробижева. М.: Институт социологии РАН; МАКС Пресс, 2009. 268 с.

Горшков М.К. (рук. коллектива). Молодежь новой России: образ жизни и ценностные приоритеты. Аналитический доклад. М.: Институт социологии РАН, 2007. 95 с.

Горшков М.К., Шереги Ф.Э. Молодежь России: социологический портрет. М.: ЦСПиМ, 2010. $592 \mathrm{c}$.

Кляус В. Л., Щапова М. Ю. Провинциальная мифология Забайкалья. Смыслы и нарративы. // Русская провинция: Миф - Текст- Реальность. Москва: изд. «Тема», 2000. С. 362-368.

Тишков В.А., Бараш Р.Э., Степанов В.В. (ред.). Российское студенчество: идентичность, жизненные стратегии и гражданский потенциал. Москва: ИЭА РАН, 2014. 342 с.

Klyaus, Marina P.

\section{General Civic and Socio-Cultural Values of Modern Youth of the Trans-Baikal Territory (Based on the Results of a Survey among Chita Students)}

\section{DOI: 10.33876/2311-0546/2021-4/49-61}

The article presents the results of a survey conducted among students of the Trans-Baikal State University at the end of 2020. The survey included questions aimed at identifying the student youth's individual values and life orientations. Current events and trends in the life of Russian society and episodes of Russian history, objects of cultural heritage, and natural resources were considered markers of civic activity and leisure preferences. The results of the survey revealed that civic identity prevails in the structure of identities. In the system of life values of young people, an important role is played by the attitude to the historical experience, traditions, and culture of their people. The Russian language dominates in communication. The survey showed that the students are oriented towards internal and external migration, and most of them are interested in volunteering.

Keywords: youth, values, questionnaire, Trans-Baikal Territory, Chita, identity

For Citation: Klyaus, M.P. 2021. General Civil and Socio-Cultural Values of Modern Youth of the Trans-Baikal Territory (Based on the Results of a Questionnaire of Chita Students). Herald of Anthropology (VestnikAntropologii) 4: 49-61.

Author Info: Klyaus, Marina P.- PhD in Hist., Institute of Ethnology and Anthropology RAS (Moscow, Russia). E-mail: marina_klyaus@mail.ru

Funding: The research was carried out within the framework of the Program of fundamental and applied scientific research "Ethno-cultural diversity of Russian society and strengthening of the all-Russian identity". The project "Russian values and symbols: national unity and ethno-cultural diversity". 


\section{Referenses}

Danilyuk, A.Ya., A.M. Kondakov, and V.A. Tishkov. 2009. Kontseptsiya duhovno-nravstvennogo razvitiya $i$ vospitaniya lichnosti grazhdanina Rossii [The concept of spiritual and moral development and education of the personality of a citizen of Russia]. Moscow: Prosveschenie.

Drobizheva, L.M. (ed.) 2009. Rossiyskaya identichnost v Moskve i regionah [Russian identity in Moscow and the regions]. Moscow: Institut sotsiologii RAN; MAKS Press.

Gorshkov, M.K. et al. 2007. Molodezh'novoi Rossii: obraz zhizni i tsennostnye prioritety [Youth of New Russia: Way of Life and Value Priorities]. Moscow: Institut sotsiologii RAN.

Gorshkov, M.K., Sheregi F.E. 2010. Molodezh'Rossii: sotsiologicheskii portret [Youth of Russia: a sociological portrait]. Moscow: TsSPiM.

Kliaus, V. L., Shchapova M. Iu. 2000. Provintsial'naia mifologiia Zabaikal'ia. Smysly i narrativy [Provincial mythology of Transbaikalia. Meanings and narratives] In Russkaia provintsiia: Mif-Tekst-Real'nost' [Russian province: Myth - Text - Reality], 362-368. Moscow: Tema.

Tishkov, V.A., Barash R.E., and V.V. Stepanov (ed.). 2014. Rossiiskoe studenchestvo: identichnost', zhiznennye strategii i grazhdanskii potentsial [Russian Students: identity, life Strategies and civic potential]. Moscow: IEA RAN. 